\title{
ДОСВІД ВИКЛАДАННЯ ТЕМИ “ЕКСТРАКЦІЯ” В КУРСІ ФІЗИЧНОЇ ТА КОЛОЇДНОЇ ХІМІЇ У ВИЩОМУ ФАРМАЦЕВТИЧНОМУ НАВЧАЛЬНОМУ ЗАКЛАДІ
}

\author{
Л. Д. Грицан
}

Національний фармащевтичний університет

\section{TEACHING EXPERIENCE OF THE TOPIC "EXTRACTION" IN THE COURSE OF PHYSICAL AND COLLOID CHEMISTRY AT THE PHARMACEUTICAL INSTITUTION OF HIGHER EDUCATION}

L. D. Grytsan

\author{
National University of Pharmacy
}

\begin{abstract}
У статті подано особливості методики викладання теми “Екстракція” в курсі фізичної та колоїдної хімії студентам, які навчаються за напрямом “Фармація", з урахуванням вимог кредитно-модульної системи.
\end{abstract}

The article reports peculiarities of the methodology of teaching the topic "Extraction" in the course of Physical and Colloid Chemistry to students specializing in Pharmacy with the emphasis on the requirements of credit-modular system.

Вступ. Впровадження у Національному фармацевтичному університеті кредитно-модульної системи організації навчального процесу відповідно до вимог Болонської конвенції зумовило значний перегляд методики викладання фундаментальних дисциплін, у тому числі фізичної та колоїдної хімії [1].

Тема "Розподіл речовини між двома рідкими фазами. Закон розподілу. Екстракція” входить як одна з складових частин до змістового модуля “Основи хімічної термодинаміки” [2-5]. Викладання цієї теми в курсі фізичної та колоїдної хімії студентам, які навчаються за напрямом “Фармація”, потребує адаптації іiі змісту з урахуванням рівня знань з фізики й математики, а також зазначеного фаху. Тому дуже важливо, з одного боку, підтримувати належний науково-методичний рівень, а 3 іншого - не переобтяжувати навчальний матеріал складними для розуміння математичними виведеннями. Обсяг лекційних, лабораторних та семінарських занять залежить від спеціальності та форми навчання. Наприклад, для студентів, які навчаються за технологічними спеціальностями “Технологія фармацевтичних препаратів", “Технологія парфумерно-косметичних засобів" та "Біотехнологія", зазначена тема повинна вивчатись більш глибоко та детально, зважаючи на широке практичне застосування процесу екстрагування.
Трикомпонентні системи, зокрема такі, які складаються $з$ двох рідких фаз і речовини, що розподілена між ними, набули широкого розповсюдження в хімікофармацевтичному та парфумерно-косметичному виробництвах, а також у біотехнології. Процес екстрагування використовують для виділення ефірних масел, алкалоїдів; на різних етапах одержання та очистки антибіотиків тощо. Його також широко застосовують у фармацевтичному аналізі, при проведенні хіміко-токсикологічних досліджень для ізолювання лікарських речовин та отрут [6-9].

Серед багатьох екологічних проблем, що потребують вирішення, проблема знесолення та очищення стічних вод підприємств хімічної та інших галузей промисловості посідає важливе місце. Сучасні методи очищення стічних вод хіміко-фармацевтичного та парфумерно-косметичного виробництв включають стадію екстракціі. Саме екстракційний метод має переваги порівняно з дистиляцією, електродіалізом та іонним обміном, тому що є найбільш економічним і не потребує великих енергетичних затрат [10].

В останні десятиріччя був впроваджений у хімікофармацевтичну та парфумерну галузі промисловості метод надкритичної флюїдної екстракції, у якому замість звичайних рідин в якості екстрагентів застосовуються гази у надкритичному стані, зокрема $\mathrm{CO}_{2}$, який має високу здатність розчиняти речовини при 
невисоких значеннях критичних параметрів $\left(\mathrm{t}_{\text {крит. }}=31,3^{\circ} \mathrm{C}, \mathrm{p}_{\text {крит. }}=7,36 \mathrm{MПа}\right), \epsilon$ нетоксичним та порівняно дешевим [7].

Зважаючи на підкреслене вище значення цієї теми, виникає необхідність приділяти певну увагу ії викладанню, постійно оновлювати зміст лекційного матеріалу та практичних занять 3 урахуванням результатів нових науково-технічних досліджень. Тому однією 3 цілей написання даної статті було бажання поділитись багаторічним досвідом викладання студентам Національного фармацевтичного університету.

Основна частина. 1 . Як відомо, теоретичною основою процесу екстракції є закон розподілу, що дозволяє кількісно описати рівновагу в трикомпонентній системі [11-17]. Тому спочатку варто розглянути його термодинамічне обгрунтування. Згідно з другим законом термодинаміки рівновага при розподілі речовини між двома рідкими фазами (I) i (II) характеризується рівністю їі хімічних потенціалів в обох фазах $\mu_{2}^{(I)}=\mu_{2}^{(I I)}$. Враховуючи, що хімічний потенціал речовини залежить від їі активності у першому $a_{2}^{(I)}$ i другому $a_{2}^{(I I)}$ розчинниках

$\mu_{2}^{(I)}=\mu_{2}^{0(I)}+R T \ln a_{2}^{(I)}, \mu_{2}^{(I I)}=\mu_{2}^{0(I I)}+R T \ln a_{2}^{(I I)}$, маємо в стані рівноваги

$\mu_{2}^{0(I)}+R T \ln a_{2}^{(I)}=\mu_{2}^{0(I I)}+R T \ln a_{2}^{(I I)}$.

Стандартні хімічні потенціали $\mu_{2}^{0(I)}$ та $\mu_{2}^{0(I I)}$ при даній сталій температурі Т є також сталими. Рівняння (1) можна привести до такого вигляду

$\frac{a_{2}^{(I I)}}{a_{2}^{(I)}}=\exp \frac{\Delta \mu_{2}^{0}}{R T}=\exp \frac{\mu_{2}^{0(I)}-\mu_{2}^{0(I I)}}{R T}=K^{0}$,

де $\mathrm{K}^{0}$ - термодинамічна константа розподілу.

Рівняння (2) є математичним виразом закону розподілу Нернста: третій компонент, який додано до системи з двох взаємно нерозчинних рідин, розподілясться між обома рідкими шарами у певному постійному за даної температури відноиенні.

Рівняння (2) можна також записати у вигляді

$K^{0}=\frac{a_{2}^{(I I)}}{a_{2}^{(I)}}=\frac{c_{2}^{(I I)} \gamma_{2}^{(I I)}}{c_{2}^{(I)} \gamma_{2}^{(I)}}=K \frac{\gamma_{2}^{(I I)}}{\gamma_{2}^{(I)}}$,

де коефіцієнт розподілу К дорівнює

$K=\frac{c_{2}^{(I I)}}{c_{2}^{(I)}}$.

Згідно з рекомендаціями IUPAC прийнято виражати коефіцієнт розподілу відношенням концентрацій речовини, що розподіляється, в органічній фазі $c_{2}^{(I I)}$ до iï концентрації у водній фазі $c_{2}^{(I)}$. Коефіцієнт розподілу на відміну від термодинамічної константи розподілу $\mathrm{K}^{0}$ залежить не тільки від температури й природи компонентів системи, а і від іонної сили розчинів, тому що від останньої залежать коефіцієнти активності $\gamma_{2}^{(I)}$ та $\gamma_{2}^{(I)}$. У розведених розчинах при $c_{2}^{(I)} \rightarrow 0$ i $c_{2}^{(I I)} \rightarrow 0 \gamma_{2}^{(I)} \rightarrow 1, \gamma_{2}^{(I I)} \rightarrow 1$, a K $\rightarrow \mathrm{K}^{0}$.

Приклад. При вивченні розподілу тимолу між ноктаном та водою при $20{ }^{\circ} \mathrm{C}$ фотометричним методом були визначені значення його рівноважних концентрацій у воді $c_{2}^{(I)}$ і н-октані $c_{2}^{(I I)}[18]$ :

\begin{tabular}{|c|c|c|c|c|c|}
\hline$c_{2}^{(I)}$, моль ${ }^{-1}$ & 4,86 & 4,81 & 4,70 & 3,30 & 3,25 \\
\hline$c_{2}^{(I I)}$, моль॰л $^{-1}$ & 2,26 & 2,25 & 2,26 & 1,52 & 1,50 \\
\hline
\end{tabular}

Обчисліть коефіцієнт розподілу.

Розв 'язок. Розрахуємо значення К для кожної пари концентрацій із використанням рівняння (4):

$\mathrm{K}_{1}=0,46 ; \mathrm{K}_{2}=0,47 ; \mathrm{K}_{3}=0,48 ; \mathrm{K}_{4}=0,46 ; \mathrm{K}_{5}=0,46$.

На підставі проведених розрахунків можна зробити висновок, що у дослідженому інтервалі концентрацій для опису фазової рівноваги у потрійній системі тимол-н-октан-вода можна застосовувати закон розподілу Нернста, тому що коефіцієнт розподілу є сталою величиною.

Практичне використання рівнянь (2)-(4) обмежено, оскільки у більшості випадків молекулярний стан речовини у відповідних розчинниках невідомий. Частіше застосовують інші рівняння, в яких ураховують вплив дисоціації і асоціації молекул речовини на величини рівноважних концентрацій, наприклад емпіричне рівняння Шилова-Лєпінь:

$K=\frac{c_{2}^{(I I)}}{\left(c_{2}^{(I)}\right)^{m}}$ або $K^{\prime}=\sqrt[m]{K}=\frac{\sqrt[m]{c_{2}^{(I I)}}}{c_{2}^{(I)}}$,

де m-величина, що не має певного фізичного смислу і залежить від температури та природи всіх трьох компонентів, які утворюють систему. Її можна представити як відношення молярних мас речовини, що розподіляється, в першому і другому розчинниках

$$
m=\frac{M_{2}^{(I I)}}{M_{2}^{(I)}} .
$$

Для ілюстрації можливості практичного застосування рівняння Шилова-Лєпінь наведемо такий приклад. 
Приклад. Розподіл фенолу між хлороформом і водою при $25^{\circ} \mathrm{C}$ характеризується такими рівноважними концентраціями $c_{2}^{(I)}$ та $c_{2}^{(I I)}$ [19]:

\begin{tabular}{|c|l|l|l|l|}
\hline$c_{2}^{(I)}$, моль॰л $^{-1}$ & 0,0737 & 0,163 & 0,247 & 0,436 \\
\hline$c_{2}^{(I I)}$, моль॰л $^{-1}$ & 0,254 & 0,761 & 1,85 & 5,43 \\
\hline
\end{tabular}

Відомо, що у водному розчині фенол є слабкою кислотою $\left(\mathrm{K}_{\text {дис. }}=1,01 \cdot 10^{-10}\right)$ та переважно існує у вигляді одинарних молекул. Який висновок можна зробити про стан молекул фенолу у хлороформі? Вважати обидва розчини практично ідеальними.
Розв'язок. Представимо рівняння (5) у лінійній формі

$$
\lg c_{2}^{(I I)}=m \lg c_{2}^{(I)}+\lg K .
$$

Параметри лінійної залежності $\mathrm{m}$ i $\lg \mathrm{K}$ визначаємо графічним методом, обчисливши попередньо значення

\begin{tabular}{|l|l|l|l|l|}
\hline $\lg c_{2}^{(I)}$ & $-1,13$ & $-0,79$ & $-0,61$ & $-0,36$ \\
\hline $\lg c_{2}^{(I I)}$ & $-0,60$ & $-0,12$ & 0,27 & 0,73 \\
\hline
\end{tabular}

Будуємо графік залежності $\lg c_{2}^{(I I)}=f\left(\lg c_{2}^{(I)}\right)$ (рис. 1) і обчислюємо $\lg K=1,27$ i $m=1,65$.
Puc. 1. Залежність $\lg c_{2}^{(I I)}=f\left(\lg c_{2}^{(I)}\right)$ для системи фенол-хлороформ-вода.

Тобто для потрійної системи фенол-хлороформвода у дослідженому інтервалі концентрацій рівняння закону розподілу має вигляд

$$
\frac{c_{2}^{(I I)}}{\left(c_{2}^{(I)}\right)^{1,65}}=18,6 .
$$

Отже, у хлороформі молекули фенолу утворюють асоціати у формі $\left(\mathrm{C}_{6} \mathrm{H}_{5} \mathrm{OH}\right)_{2}$.

Треба зауважити, що розв'язання наведеної задачі можна виконати і з використанням обчислювальної техніки, застосовуючи метод найменших квадратів. Однак графічний метод має перевагу як більш наочний і такий, що сприяє кращому засвоєнню навчального матеріалу студентами.

Подібні розрахунково-графічні завдання за бажанням викладача можуть надаватися студенту в якості позааудиторної самостійної роботи для одержання додаткових балів.

2. При переході до розгляду процесу екстракції вар-

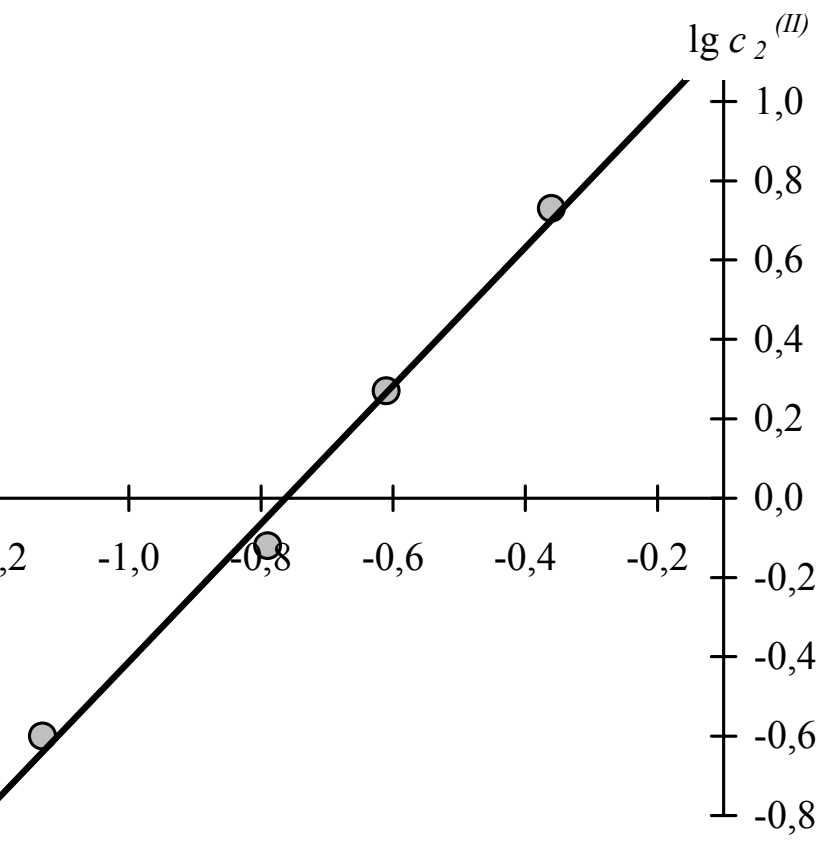

то знову підкреслити, що згідно з другим законом термодинаміки він перебігає самочинно, внаслідок чого вирівнюються хімічні потенціали речовини у фазах, які контактують.

Для аналізу простої екстракційної системи (двофазної, складеної з трьох компонентів), яка знаходиться у стані рівноваги, можна застосовувати правило фаз Гіббса. За умов незмінності температури і тиску одержимо, що варіантність системи (число їі термодинамічних ступенів свободи) дорівнюватиме одиниці. Це означає, що існує взаємно однозначна відповідність між рівноважними концентраціями компонента, що розподіляється між двома рідкими фазами - такою, за допомогою якої екстрагують, і 3 якої проводять добування третього компонента. Тому для кількісної характеристики рівноважного розподілу застосовують коефіцієнт розподілу, за величиною якого судять про екстракційну здатність екстрагента: чим більшим буде цей параметр, тим вищою буде здатність даного розчинника екстрагувати цільовий 
компонент. Наведемо такий приклад.

Приклад. При температурі $20^{\circ} \mathrm{C}$ і концентраціях, що виключають помітну димеризацію тимолу в обох фазах, визначено коефіцієнти розподілу тимолу між хлороформом та водою, тетрахлоридом вуглецю та водою, н-октаном таводою, які дорівнюють 630, 245 та 48 відповідно. Який з органічних розчинників слід вибрати для найбілыш повного добування тимолу з водних розчинів?

Для відповід $i$ на це запитання студент повинен порівняти надані значення коефіцієнтів розподілу тимолу між різними органічними розчинниками та водою. В даному випадку доцільно буде вибрати хлороформ, екстракційна здатність якого найвища.

3. Для проведення рідинної екстракції використовують спеціальні апарати - екстрактори з однократним і багатократним контактом фаз, в які поміщають вихідну суміш та розчинник (екстрагент). Відповідно розрізняють однократну (одноступеневу) i багатократну (багатоступеневу) екстракції. Одноразова екстракція, яка здійснюється періодично або безперервно, можлива лише при високих значеннях коефіцієнта розподілу і застосовується переважно для аналітичних цілей. Багатократна екстракція, яка найбільш поширена у промисловості, проводиться безперервно. Найчастіше використовують протитечійну екстракцію одним екстрагентом 3 кількістю ступенів зазвичай 5-10 (для компонентів, які важко розділяються, число ступенів може досягати 70-100).

Для підвищення ефективності екстракції підбирають такі умови ії проведення (додавання електролітів або інших добавок, температура, pH тощо), за яких зменшується вплив побічних реакцій, наприклад дисоціації, асоціації та ін.

Розрахунок кількісних характеристик рідинної екстракції грунтується на законі розподілу речовини між двома розчинниками, що не змішуються. Для обчислення матеріального балансу при одноступеневій екстракції застосовується рівняння

$m_{1}=m_{0} \frac{V_{0}}{V_{0}+K V}$

а при багатоступеневій екстракції

$m_{n}=m_{0}\left(\frac{V_{0}}{V_{0}+K V}\right)^{n}$

де $\mathrm{m}_{0}$ - кількість речовини, яка добувається, у вихідному розчині; $\mathrm{V}_{0}$ - об'єм вихідного розчину; $\mathrm{V}$ об'єм порції екстрагенту; n - кратність екстракціі; $\mathrm{m}_{1}$ - кількість речовини, що добувається, яка залишилась у вихідному розчині; $m_{n}$ - кількість речови- ни, яка залишилась у вихідному розчині, після n-кратного екстрагування.

Розглянемо приклад розрахунку матеріального балансу та кратності екстракції, необхідної для зниження вмісту шкідливих для навколишнього середовища речовин до гранично допустимої концентрації (ГДК).

Приклад. Одним з ефективних способів очистки фенольних стічних вод хіміко-фармацевтичного та парфумерно-косметичного виробництв є екстракція фенолів органічними розчинниками [9]. Розрахуйте кількість фенолу (у грамах), яку можна добути 35 м $^{3}$ водного розчину, що вміщував спочатку 0,80 г фенолу, одноразовою екстракцією 50 дм $^{3}$ н-бутилацетату. Коефіцієнт розподілу фенолу між н-бутилацетатом і водою дорівнює 48,5 при $20{ }^{\circ} \mathrm{C}$. Якою повинна бути кратність екстракції n, щоб вміст фенолу у стічних водах не перевищував його ГДК у водоймищах $\left(0,05\right.$ мг・дм $\left.{ }^{-3}\right)$ ?

Розв 'язок. 1) Масу фенолу, який залишився у водному розчині після однократної екстракції, розрахуємо за рівнянням (6)

$$
m_{1}=0,80 \frac{5}{5+48,5 \cdot 50 \cdot 10^{-3}}=0,54_{\Gamma} .
$$

В органічну фазу перейшло 0,80-0,54=0,26 г фенолу. 2) Для розрахунку кратності екстракції використаємо рівняння матеріального балансу при багатоступеневій екстракції (7). Після його логарифмування і розв'язання у загальному вигляді відносно n одержуємо

$$
n=\frac{\lg m_{n}-\lg m_{0}}{\lg V_{0}-\lg \left(V_{0}+K V\right)} .
$$

Підстановка чисельних значень $\mathrm{m}_{\mathrm{n}}=5 \cdot 10^{-5} \Gamma^{\bullet} \mathrm{дм}^{-3}$; $m_{0}=\frac{0,80 \Gamma}{5000 \text { дм }^{3}}=1,6 \cdot 10^{-4} \Gamma \cdot$ дм$^{-3} ; \mathrm{V}_{0}=5000$ дм $^{3} ;$ $\mathrm{K}=48,5 ; \mathrm{V}=50$ дм$^{3}$ дає $\mathrm{n}=3$. Тобто достатньо провести трикратну екстракцію для зниження вмісту фенолу до ГДК.

4. У зв' язку з вимогами Болонської системи зменшується кількість аудиторних занять (зокрема лекційних), тому важливого значення набуває навчально-методичне забезпечення та організація самостійної роботи студентів. У підручнику $[12,13]$ i задачнику [18] викладення теоретичного матеріалу супроводжується прикладами розв'язання фахових задач, а також надаються задачі і запитання для самопідготовки студентів й контролю якості засвоєння кожної теми. До збірника тестових завдань [20] включена низка тестів за темою “Екстракція”. Для ілюстрації наведемо одне з таких завдань. 
Приклад. Екстракція широко використовується для вилучення біологічно активних речовин з рослинної сировини. Її ефективність оцінюють за величиною:

А.* Коефіцієнта розподілу.

В. Коефіцієнта активності.

C. Коефіцієнта дифузії.

D. Ізотонічного коефіцієнта.

Е. Коефіцієнта поглинання.

* позначає правильну відповідь.

Подібні завдання обов'язково розбираються при проведенні практичних занять, а також пропонуються студентам для самостійної роботи і включаються до білетів модульного контролю.

Треба зазначити, що закріплення здобутих теоретичних знань, а також ознайомлення $з$ сучасними фізико-хімічними методами досліджень краще за все відбувається під час лабораторного практикуму [21]. При виконанні лабораторних робіт “Вивчення розпо-

\section{Лiтература}

1. Кредитно-модульна система організації навчання у контексті Болонського процесу в Національному фармацевтичному університеті : навч.-метод. посіб. / [В. П. Черних, В. М. Толочко, Л. Г. Кайдалова та ін.]. - Харків : Вид-во НфаУ, 2004. $-68 \mathrm{c}$.

2. Програма з фізичної та колоїдної хімії для студентів вищих фармацевтичних закладів освіти та фармацевтичних факультетів вищих медичних закладів освіти III-IV рівнів акредитації / [В. І. Кабачний, Л. Д. Грицан, Л. К. Осіпенко та ін.]. - Київ, 1998. - 24 с.

3. Програма з фізичної та колоїдної хімії для студентів спеціальності 7.110204 “Технологія фармацевтичних препаратів" вищих закладів освіти III-IV рівнів акредитації / [В. I. Кабачний, Л. Д. Грицан, Л. К. Осіпенко та ін.]. - Київ, 2000. - 28 с.

4. Кабачний В. І. Програма з фізичної та колоїдної хімії для студентів напряму 6.051401 “Біотехнологія” вищих закладів освіти III-IV рівнів акредитації / В. I. Кабачний, Т. О. Томаровська, Л. Д. Грицан. - Київ, 2007. - 7 с.

5. Програма з фізичної та колоїдної хімії для студентів вищого фармацевтичного навчального закладу та фармацевтичних факультетів вищих медичних навчальних закладів III-IV рівнів акредитації. Напрям: “Фармація”. Спеціальність: “Технологія парфумерно-косметичних засобів” / [В. І. Кабачний, Т. О. Томаровська, Л. Д. Грицан та ін.]. Київ, 2011.-64 с.

6. Державна Фармакопея України. - Харків : РІРЕГ, 2001. $-556 \mathrm{c}$.

7. Химическая энциклопедия : в 5 т. Т. 5. - М. : Большая российская энцикл., 1998. - С. 414-422.

8. Екстракція / [Л. Д. Грицан, Т. О. Томаровська, О. І. Зайцев та ін.] // Фармацевтична енциклопедія. - К. : Моріон, 2010.-C. $494-495$.

9. Коренман И. М. Экстракция в анализе органических веществ / И. М. Коренман. - М. : Химия, 1977. - 200 с. ділу речовини між двома рідкими фазами” та “Однократна та багатократні екстракції” студенти набувають практичних вмінь і навичок, які будуть закріплюватись при вивченні таких профільних дисциплін, як: “Технологія ліків”, “Технологія парфумерно-косметичних засобів”, “Біотехнологія” тощо.

Висновки: 1. Організація навчального процесу повинна бути такою, щоб підготувати студентів до опанування спеціальних дисциплін на старших курсах і подальшої професійної діяльності.

2. При розподілі обсягу навчального матеріалуміж аудиторними заняттями та самостійною роботою студентів необхідно враховувати спеціальність та форму навчання.

3. Для кращого засвоєння програмного матеріалу доцільно наводити приклади і підбирати задачі, які відбивають певні проблемні ситуації, що виникають у практичній діяльності фахівців хіміко-фармацевтичної, парфумерної та біотехнологічної галузей.

10. Новые методы опреснения воды / [Л. А. Кульский, А. С. Чепцов, Т. В. Князькова и др.]. - К. : Наукова думка, 1974. -192 c.

11. Красовский И. В. Физическая и коллоидная химия / И. В. Красовский, Е. И. Вайль, В. Д. Безуглый. - К. : Вища школа, 1983. $-352 \mathrm{c}$.

12. Фізична і колоїдна хімія / [В. І. Кабачний, Л. К. Осіпенко, Л. Д. Грицан та ін.] - Харків : Прапор, Вид-во НФаУ, 1999. $-368 \mathrm{c}$.

13. Физическая и коллоидная химия / [В. И. Кабачный, Л. К. Осипенко, Л. Д. Грицан и др.]. - Харьков : Изд-во НФаУ, 2010. $-432 \mathrm{c}$.

14. Евстратова К. И. Физическая и коллоидная химия / К. И. Евстратова, Н. А. Купина, Е. Е. Малахова. - М. : Высш. шк., 1990. -487 c.

15. Лебідь В. І. Фізична хімія / В. І. Лебідь. - Харків : Гімназія, 2008. $-478 \mathrm{c}$.

16. Физическая химия: в 2 кн. Кн. 1. Строение вещества. Термодинамика / [К. С. Краснов, Н. К. Воробьёв, И. Н. Годнев и др.]. - М. : Высш. шк., 2001. -512 с.

17. Стромберг А. Г. Физическая химия / А. Г. Стромберг, Д. П. Семченко.-М. : Высш. шк., 2001.-527 с.

18. Фізична та колоїдна хімія. Збірник задач / [В. І. Кабачний, Л. К. Осіпенко, Л. Д. Грицан та ін.]. - Харків : Вид-во НФаУ; Вид-во ТОВ “Золоті сторінки”, 2001.-208 с.

19. Краткий справочник физико-химических величин / под ред. А. А. Равделя и А. М. Пономарёвой. - С.Пб.: Специальная Литература, 1998. - 232 с.

20. Сборник тестовых заданий по физической и коллоидной химии / [В. И. Кабачный, Л. Д. Грицан, Л. К. Осипенко и др.]. - Харьков : Изд-во НФаУ, 2007. -224 с.

21. Фізична та колоїдна хімія. Лабораторний практикум / [В. І. Кабачний, В. П. Колєснік, Л. Д. Грицан та ін.]. - Харків : Вид-во НФаУ: Золоті сторінки, 2004.-200 с. 